\title{
COVID 19 Impact on Air Transport Industry and Recovery Policy
}

\author{
Sorin Eugen Zaharia ${ }^{1}$, Casandra Venera Pietreanu ${ }^{2}$, Adina Petruta Pavel ${ }^{3}$ and \\ Ruxandra - Elena Boc ${ }^{4}$ \\ 1)2334) Politehnica University of Bucharest, Bucharest, Romania \\ E-mail: sorin.zaharia@gmail.com; E-mail: casandra.pietreanu@yahoo.com \\ E-mail: adinappavel@gmail.com; E-mail: ruxandra.elena.boc@gmail.com
}

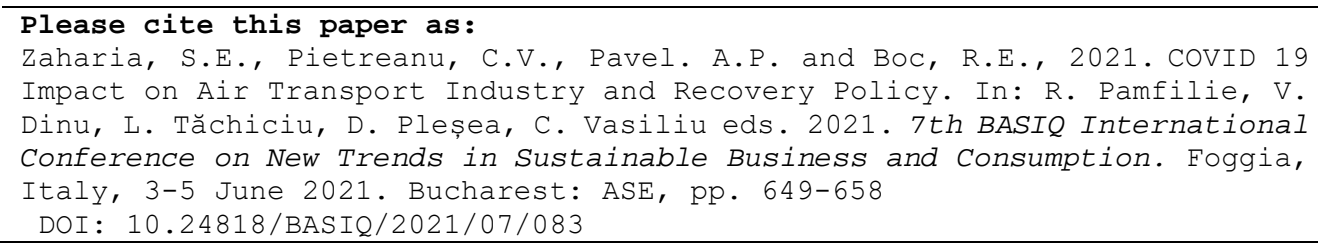

\section{Abstract}

Aviation has changed people's lives all around the globe, boosted the service industry, included tourism and played a major role in the recent economic growth. Air transport is a vital key for the global economy facilitating access to any product or labour market and having the capacity to transform a local business into a global one, especially in developing countries.

The purpose of the paper is to analyse the impact of pandemic COVID 19 on air transport passenger traffic in a holistic approach, its domino effect on air companies, airports and aircraft factories evolution in 2020 and 2021. The research methods are a data-based analysis of air transport evolution at both European and global level considering the documents published by IATA, ICAO and ACI, and structured interviews with representatives of airports, airlines and maintenance providers.

Our analysis provides policymakers with strategic information concerning some of the most important performance indicators of air transport, as RPK, passenger traffic, air routes served by European airports, passenger revenues evolutions, net profits of the airline industry. The target group consists of airlines, European airports and major aircraft manufacturers. This analysis could be the baseline for building air transport recovery strategies for $2021-2024$.

Keywords: Air transport, COVID-19, airlines, airports, aircraft manufactures, RPK, passenger traffic. DOI: 10.24818/BASIQ/2021/07/083

\section{Introduction}

Aviation has changed people's lives, boosted the service industry, included tourism and played a major role in the recent economic growth. Air transport is a vital key for the global economy facilitating access to any product or labour market and having the capacity to transform a local business into a global one, especially in developing countries.

The data show that 12.5 million passengers travelled by plane, 128,000 scheduled flights were made, and $\$ 18$ billion worth of goods were transported by day in 2019 .

In 2018, the airline industry generated 87.7 million jobs globally, providing 11.3 million direct jobs. Airlines, air navigation service providers and airports directly employ almost 4.5 million people, and the civil aerospace sector, which produces aircraft, structures and engines, employs 1.2 million people. In addition, 5.5 million people work in other positions at the airport. There are also 18.1 million indirect jobs generated through the purchase of goods and services from various companies through the supply chain of the air transport industry. Employees 'wages in the airline industry support spending for 13.5 million induced jobs. Aviation-facilitated tourism generates approximately 44.8 million jobs globally. 


\section{A $0.1 \mu \mathrm{m}$ intruder produces a domino effect on aviation}

\section{Dramatic decrease in passenger traffic}

In the first two quarters of 2020, all forecasts were brutally invalidated by the unexpected arrival of a $0.1 \mu \mathrm{m}$ intruder called SARS CoV-2. Isolation policies imposed by many governments starting with March 2020 and travelling plans cancelled by anxious passengers produced a dramatic air traffic backdrop. There were about 7.5 million flights cancelled during the first half of the year 2020. 12 of April became the day of 2020 with the fewest flights in recent years, only 46,294. Since that day, the total number of flights pursued by Flightradar24 has increased, even though commercial traffic has roughly remained the same during the whole month of April 2020. The busiest flight day was the 28th of April, the day when Flightradar24 registered 80,714 flights only. It was a 40\% decrease if compared with the same period of 2019 when the number of registered flights was 203,239. A slight increase of 29,439 flights average per day was registered at the end of April 2020. The level stayed low if compared with 111,799 flights per day in 2019. A modest recovery trend was observed in June 2020, even though remaining at $-90 \%$ on the 28 th of June compared to $-94 \%$ on the 15 th of June and $-97 \%$ on the 1 st of June. (ACI - Europe, 2020). The International Air Transport Association (IATA) statistics (IATA Economics, 2020) indicates for December 2020 a volume of passenger traffic between -94.7\% in AsiaPacific and $-68.8 \%$ in Africa compared to the same period in 2019 (Table no. 1). In December 2020, the RPK recorded a decrease by $82.3 \%$ in Europe.

Table no. 1. Changing of RPKs in 2020 vs 2019 by regions of airline registration

\begin{tabular}{|l|l|l|l|}
\hline Region of airline registration & \multicolumn{1}{|c|}{$\begin{array}{c}\text { RPKs 2020 vs 2019 } \\
(\%)\end{array}$} & Region of airline registration & RPKs 2020 vs 2019 (\%) \\
\hline Asia - Pacific & -61.9 & Middle East & -72.2 \\
\hline North America & -65.2 & Africa & -68.8 \\
\hline Europe & -69.9 & Latin America & -62.1 \\
\hline Air Transport Industry & \multicolumn{2}{|c|}{$\mathbf{- 6 5 . 9}$} \\
\hline
\end{tabular}

\section{Drastic decrease in airline revenues}

In February 2020, IATA (IATA Economics, 2020) estimated that, globally, airlines will record \$ 113 billion in revenue from passenger traffic less than a year ago. In July, the figure reached \$ 419 billion. By mid-April, more than $80 \%$ of the global fleet was grounded. Airports around the world were either closed or operating at a very low level. The staff has been reduced throughout the sector, and several airlines have started insolvency proceedings. Subsequently, the losses at the level of 2020 were estimated at 252 billion dollars, which means a decrease in revenues by $38 \%$ compared to the previous year (Figure no. 1).

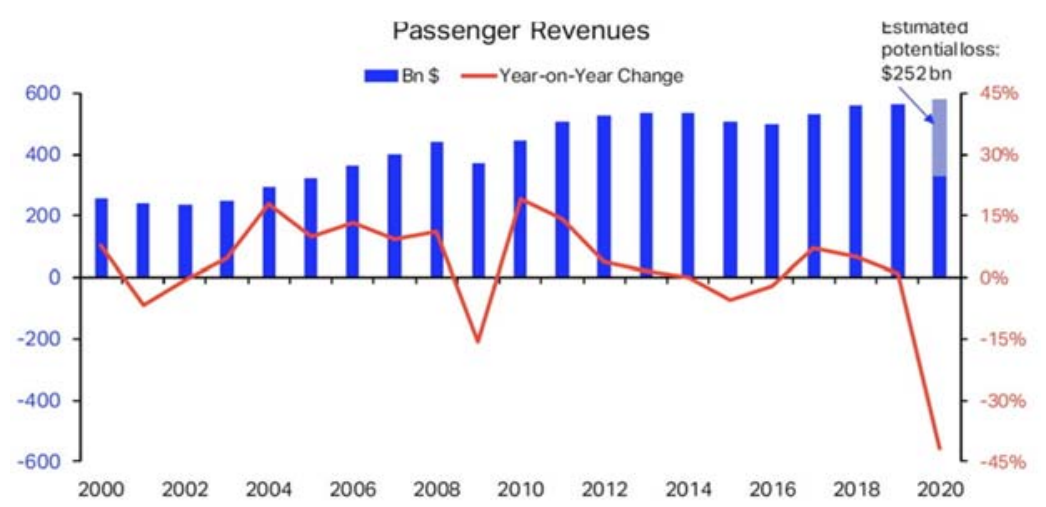

Figure no. 1. Passenger Revenues Evolutions Source: IATA Economics, 2020 
The 2008 crisis contributed to the air traffic knockdown with a certain time lag comparing with the economic collapse, whereas the air traffic stopped at the same time as the economy due to the pandemic in 2020. Figure no. 2 illustrates the effect that the 2020 crisis had on global GDP in that period, but also the estimations for the 2021-2023 (Oxford Economics, 2020).

IATA has estimated revenue losses of approximately \$ 16.4 billion and \$ 37.1 billion in 2020 for airports in North America and Europe and over \$ 314 billion dollars for airlines between January 1st and June 28th 2020 (E. Măzăreanu, 2020). 24 airlines ceased operations or entered into bankruptcy due to the crisis between February and August 2020, including Atlas Global (Turkey), Eurowings (Germany), Flybe (UK), Air Mauritius, Virgin Australia etc.

Many companies were saved by state aids, such as Lufthansa, in which the German government bought $20 \%$ of the company's shares. Tarom and Blue Air are also receiving financial assistance from the Romanian government.

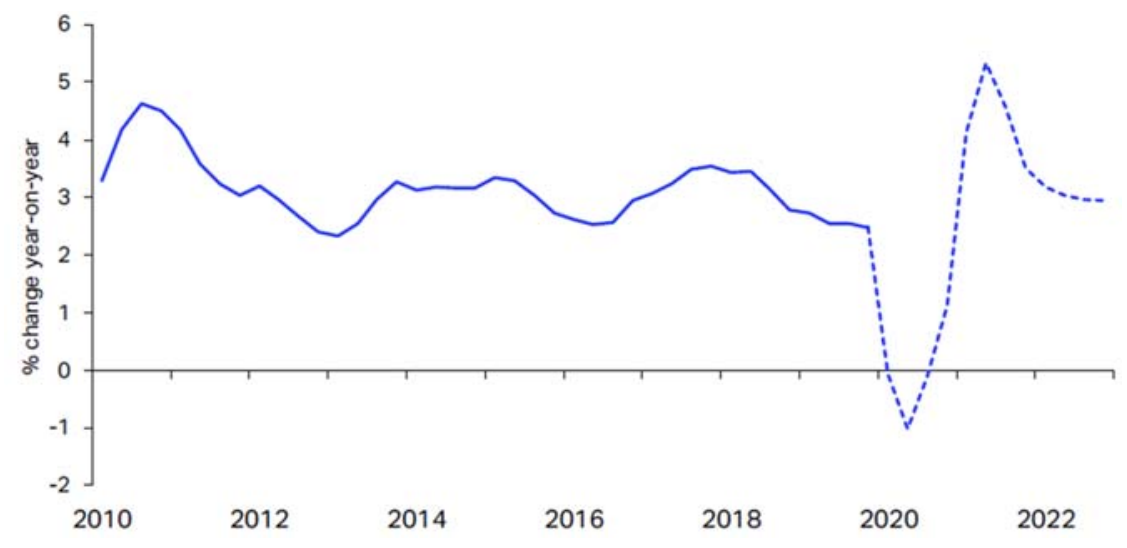

Figure no. 2. Global Gross Domestic Product GDP growth

Source: Oxford Economics, 2020

\section{Massive layoffs among airline employees}

The dramatic drop in air traffic caused by the pandemic and the worldwide airlines' decline has led to massive layoffs among their employees. Airlines had to find quick solutions to air traffic decline, which means either stopping all orders for new aircraft and components or firing many employees. Airline cash was quite fragile even before the pandemic. A study conducted for IATA by McKinsey (IATA Economics, 2020) on 120 airlines shows that only a quarter of them made a profit in 2018. Most of them were heavily indebted as a result of ambitious investments in new aircraft.

The pandemic has further aggravated the situation of airlines, which had to return about $\$ 35$ billion for tickets sold for not operated flights in the second quarter of 2020. Operating losses in the second quarter are estimated to a total of \$ 61 billion (Figure no. 3). The enormous losses of 2020 will marginally harm the operating gains of 2021.

The share price of the airlines had already decreased since the end of 2019, which made it more difficult to capitalize later on them. The pandemic further aggravated the situation, so the value of shares continued to fall to less than half of the initial value in the first five months of 2020 . Even if governments have provided financial support to them, some airlines could either go bankrupt or survive if they significantly reduce their size. Surviving players in the market have serious reasons to be prudently and to postpone staffing, route expansion and equipment purchases in the given situation. 


\section{BASIQ INTERNATIONAL CONFERENCE}

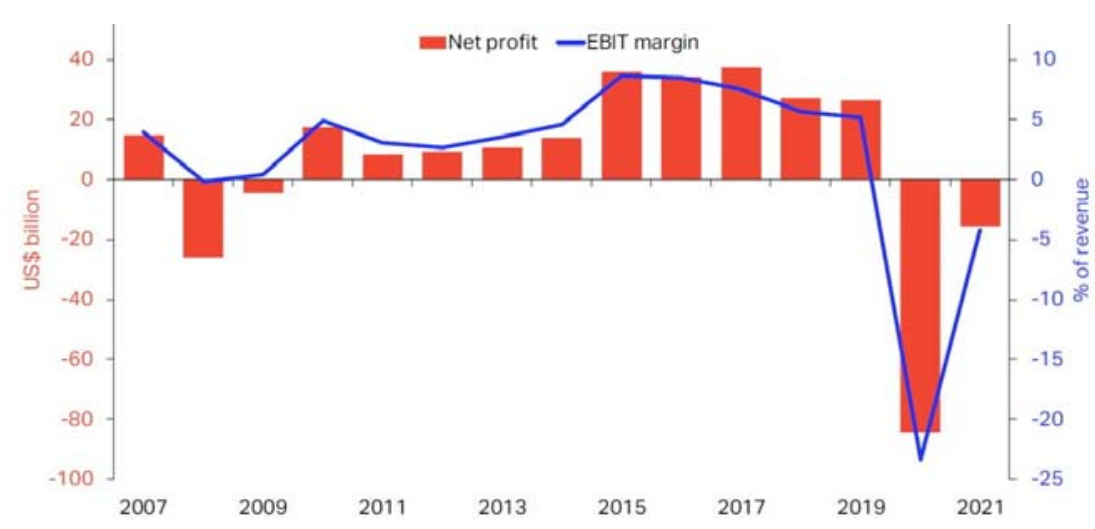

Figure no. 3. Net profits of the airline industry and EBIT margin

Source: IATA Economics, 2020

Air France and HOP! have taken rigorous decisions to save current and future costs. These airlines had $95 \%$ lower revenues in the first three months of the pandemic, in other words, they had losses of 15 million EUR per day. The French state has been aware of this situation and has lent them 7 billion euros to withstand the crisis in the short term, until they can get back on their own feet. At the moment, the solution would be workforce's restructuring and reorganization. Air France is forced to reduce approximately 6,560 jobs by the end of 2022, and HOP! is obliged to reduce 1,020 jobs by the end of 2023 (Prokopovič, 2020). Lufthansa estimates that it needs to reduce 22,000 jobs, both for seafarers and for management or administration positions despite the support received from the German government. (BBC News, 2020).

Airlines companies have reduced or announced further job cuts in a large number, such as: Ryanair 3,000 jobs to survive in the next 12 months; Virgin Atlantic 3,000 jobs; British Airways 12,000 jobs; EasyJet by 4,500; Tarom by 400 jobs; Virgin Australia has reduced 8,000 out of 10,000 employees (Digi 24, 2020).

\section{Decreased airport revenues}

With some markets seeing almost three-digit declines in passenger traffic, airport activity immediately felt these declines in financial terms. Losing consumer confidence also means time for the industry to recover. These airport revenues help cover capital costs and operating expenses, as well as personnel costs. At present, estimates indicate airport industry losses of up to $\$ 70$ billion compared to the preCOVID-19 core value for 2020. At airports in Europe, passenger traffic and airlines decreased by about the same percentage of $-64.2 \%$ in the first half of 2020 . Regarding the second quarter of 2020 , airports almost reached a total blockage with a decrease of $-96.4 \%$, compared to the same period last year (ACI - Europe, 2020).

In the first half of the year 2020, the decrease in passenger traffic was less pronounced on the non-EU market $(-59.8 \%)$ than in the EU (-65.6\%) (ACI - Europe, 2020). The difference in traffic reduction reflected less severe blockages in several non-EU countries. These were visible at a time when domestic air services were less affected than international services. The decrease in domestic traffic was less acute on non-EU airports $(-50.7 \%)$ than on the EU $(-62.9 \%)$ ones, while passenger volumes on international routes decreased at the same rate on both non-EU and EU airports with $-65.1 \%$ and $65.4 \%$, respectively. That was especially the case of the airports in Russia, Norway and, to a lesser extent, in Turkey (ACI - Europe, 2020).

All these significant decreases have led to changes in the ranking of the top five European airports. In June 2020, when there was a decrease in passenger traffic in the European airport network by $-93.3 \%$, Moscow-Domodedovo became the busiest European airport, with 716,800 passengers (-73.3\%), followed by Paris-CDG (625,900 passengers, $-90.9 \%)$, Moscow-Sheremetyevo (622,800 passengers, $86.5 \%)$, Frankfurt (599,200 passengers, $-90.9 \%)$ and Istanbul (591,000 passengers, $-90.1 \%)$. London- 
Heathrow (-95.2\%) has held first place in Europe for several consecutive years. In June 2020 it reached $11^{\text {th }}$ place, with just over 350,700 passengers compared to 7.24 million in June 2019. Amsterdam Schiphol, the third busiest airport in Europe in 2019, dropped to 7 th place, with 471,800 passengers ( $-92.7 \%$ ). The changes in the ranking were not limited to the top five European airports, but spread to a whole list of airports, reflecting the lack of coordination between European states in lifting travel restrictions: Athens (-87.9\%) and Izmir (-77.7\%) registered more passengers than Munich (-95.1\%); Sochi (-70.8\%) more than Madrid (-96.5\%) and Zurich (-93.3\%); Trondheim (-77.3\%) and Catania (91.1\%) more than Brussels (-96.4\%) and Helsinki (-96\%) (ACI - Europe, 2020).

Passenger traffic and the number of aircraft movements have increased slightly since then, with an acceleration in July but followed by a traffic stagnation in August due to the resurgence of restrictions imposed by some states whenever the cases of COVID-19 increase in number. The recovery rate at the end of 2020 and the beginning of 2021 continues to be slow. In January 2021, Europe's airports recorded a decrease in passenger traffic of $-80.6 \%$ compared to January 2020 and $-80.2 \%$ compared to January 2019. The decrease was more pronounced on the EU/EEA/Swiss/UK airports (-86\% vs. $2020 \mid-85 \%$ vs. 2019) than on other European airports (-58\% vs. $2020 \mid-57 \%$ vs. 2019) (Figure no. 4).

The downward trend was particularly acute on EU/EEA/Swiss/UK airports in January 2021, with the last week of the month at $-88 \%$ due to a widespread tightening of travel restrictions, including a nonessential travel blanket negative advice/prohibition. The worst performance came from the UK (-92\%) on 31 January, closely followed by Germany (-89\%), the Benelux \& Nordics/Baltics (-88\%), then Italy $(-87 \%)$, Eastern EU (-84\%) and France (-73\%). Conversely, the rest of the European market saw passenger traffic improving slightly over the month from $-60 \%$ to $-56 \%$, reflecting much less restrictive travel and the resilience of domestic markets, as in Russia and Turkey. Figure no.5 presents the passenger traffic data for 15 March 2020 to 31 January 2021, based on data received from members accounting for $82 \%$ of total European passenger traffic. Since 1 March 2020, Europe's airports have lost 1.86 billion passengers compared to business forecasts for 2020, which foresight an increase of $2.3 \%$ compared to 2019 .

In the ranking of the top ten European airports for April 2021, IGA Istanbul Airport ranks first as the busiest European airport, with 641 flight per day (week 8-14/4) (-43\% vs 2019). The Turkish airport was followed by Frankfurt (526 flights, -64\%), Paris-CDG (480 flight, - 67\%), Amsterdam (472, $67 \%$ ), and Madrid/Barajas (403, -65\%), Istanbul/Sabiha Gokcen (395 flight, -35\%), London/Heathrow (348, -74\%), Palma De Mallorca (242, -62\%), Munich (233, -80\%), Athens (218, -62\%).

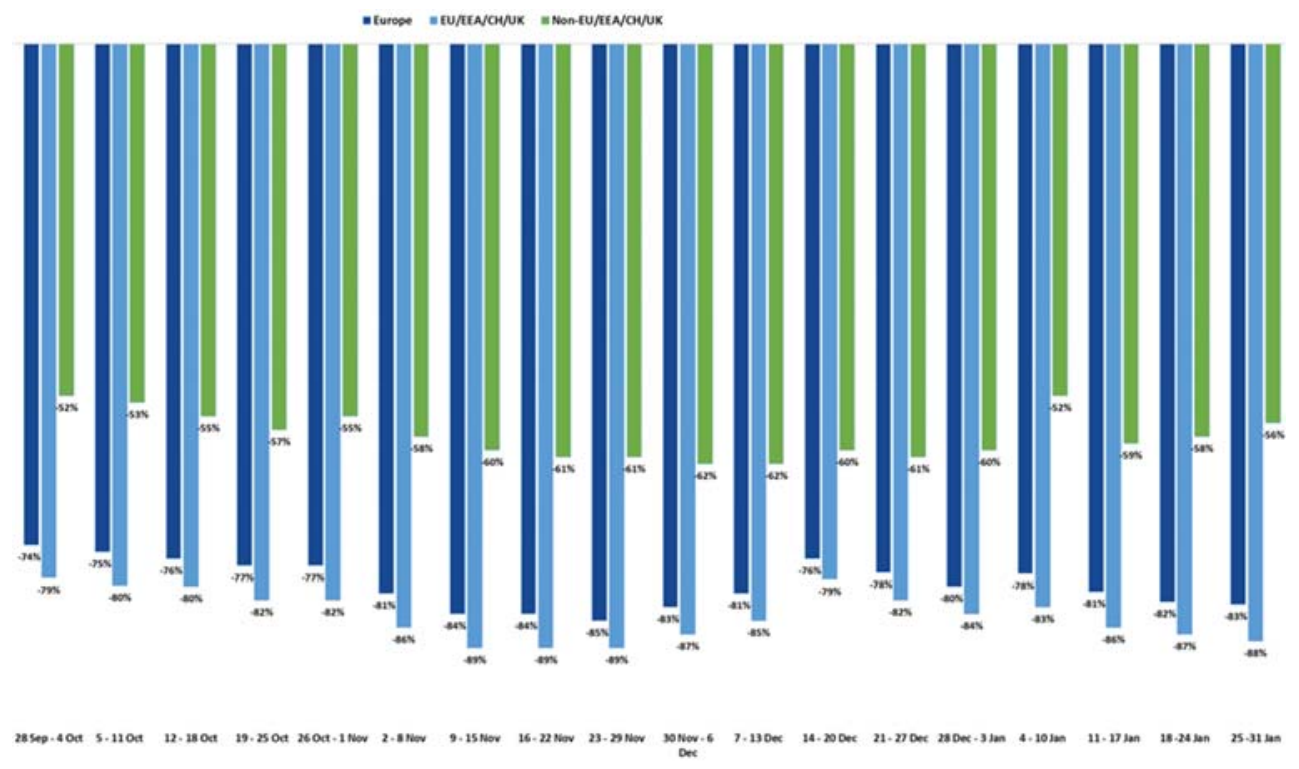

Figure no. 4. Airport Passenger Traffic - Weekly Passenger Developments Source: ACI- Europe, 2021 


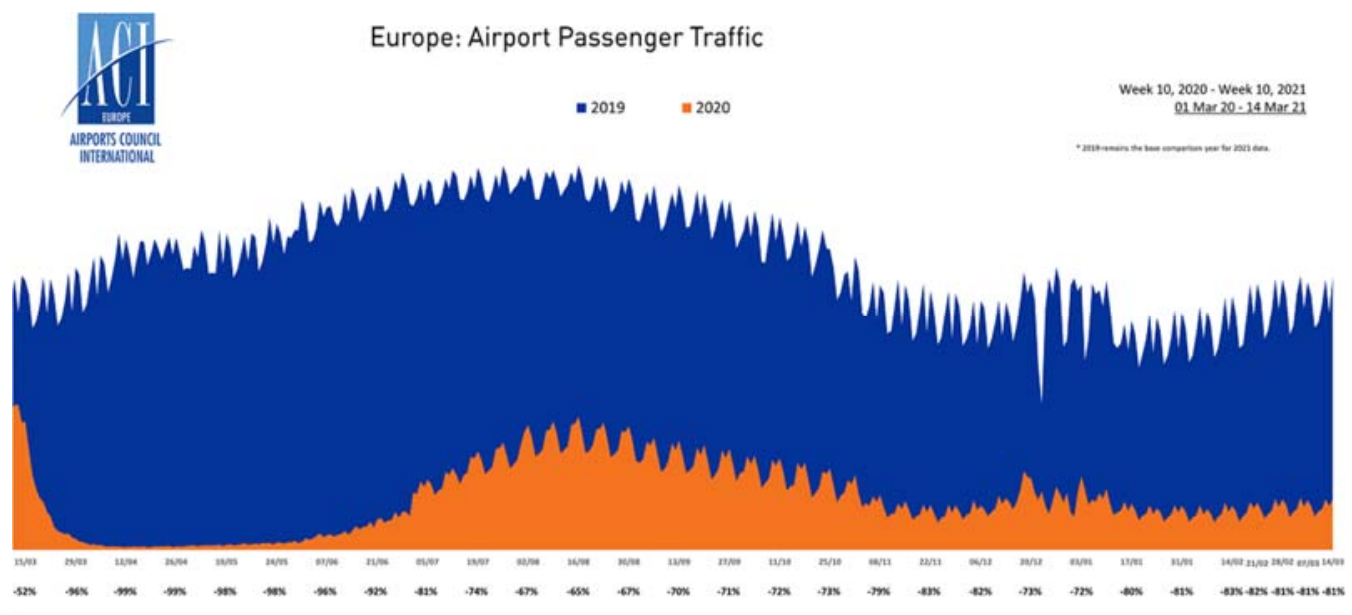

Figure no. 5. The evolution of passenger traffic in Europe between $15^{\text {th }}$ of March 2020 and 2021 Source: ACI-Europe, 2021

The total number of air routes served by European airports at the end of 2020 and first quarterly of 2021 is presented in Figure no. 6.

Massive layoffs also took place at airports. Copenhagen Airport alone has laid off 650 employees. Heathrow Airport Group reduced more than 30\% of management positions. Handling companies are also not immune to financial suffering and, implicitly, redundancies. Swissport airport handling company plans to cut more than 4,500 jobs in the UK due to the pandemic.

\section{Aircraft are rapidly becoming victims of Coronavirus}

The global economic downturn triggered by the Covid-19 pandemic, but with older roots, is very likely to go far beyond this year. As a result of this recession and the immediate consequences already presented, frequent cancellations and rescheduling of airliners orders can be expected, with huge effects on producers' business. Boeing and Airbus will be severely affected by the slowdown development of air transport, and their production rates will need a serious adjustment, with their financial performance declining considerably.

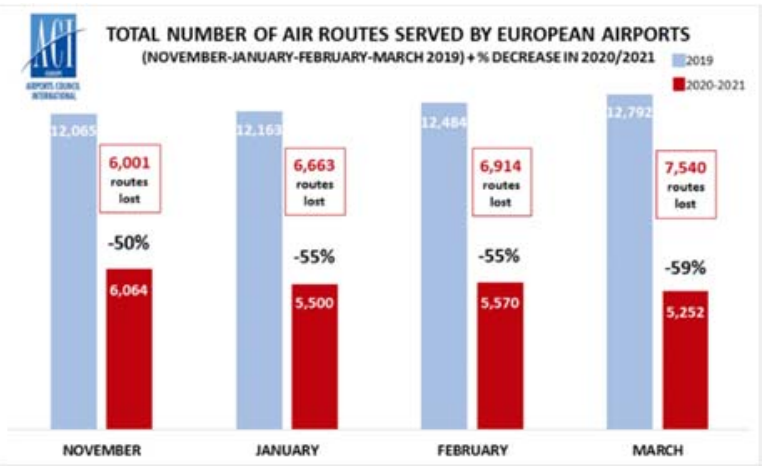

Figure no. 6. Total number of Air routes served by European airports Source: ACI-Europe, 2021 
Boeing was already in a delicate situation at the start of the pandemic after suffering heavy losses in 2019 due to the grounding of 737 Max aircraft even though the US Government promised a \$60 billion bailout. European governments should also be prepared to do the same for Airbus if a recession strikes as its activity for the defence industry is less developed than the Boeing one with $\$ 26$ billion annually sells to the sector. Airbus covering losses from the sale of commercial products with gains from military sales sounds not very genuine. However, neither of the two producers will be relieved of difficulties shortly. They had been supposed to deliver approximately 2,700 aircraft worldwide by $2020-21$. Both companies were already hit by an avalanche of order cancellations in the first six months of 2020. 27 Boeing 737MAX aircraft orders were cancelled by Aircraft leasing company Avolon alone (Prokopovič, 2020).

Large second-hand owned fleets, bankruptcies' discouragement, and enormous financial difficulties of the surviving airlines add together and lead to a significant number of order cancellations for new aircraft and more new orders shortage. Moreover, it will create hard times for aircraft manufacturers. Astonished by the shock of the 2020 crisis, giant manufacturers as Airbus and Boeing have refrained from making updated forecasts anymore as being busy recording the flow of order cancellations and reducing production volume. Boeing's operating income, reported at the end of March 2020, was \$16.9 billion, 26\% lower compared to the same period of previous year. Boeing recorded a profit of $\$ 2.15$ billion in the first quarter of 2019, but had a loss of $\$ 628$ million in the same period of 2020. As for Boeing's indebtedness, it exceeded the level of assets, reaching $106.5 \%$ at the end of March 2020 (TradeVille, 2020).

On the other hand, Airbus had operating revenues of EUR 10.6 billion in the first quarter of this year, which are $15 \%$ lower than the same period of last year. The total losses recorded by Airbus in the first 3 months of 2020 were EUR 481 million compared to the same period of last year, when they had a profit of EUR 40 million. Airbus CEO Guillaume Faury estimates (TradeVille, 2020) a 40\% reduction in production over the next two years caused by the COVID-19 epidemic. The company expects deliveries to decrease by $40 \%$. The Chamber of Commerce and Industry of Occitania, the French region where Airbus aircraft are produced, estimates that this year Airbus will reduce parts purchases by $50 \%$ (TradeVille, 2020). Around 40,000 jobs will be directly affected locally, and another 40,000 jobs will be indirectly affected by this. Boeing has already announced that the first 6,770 employees are to be laid off in the United States. Airbus announced already plans to adapt its global workforce on 30 June 2020. Moreover, the company resized its commercial aircraft activity in response to the COVID-19 crisis (Airbus, 2020), resulting in a reduction of approximately 15,000 positions by the summer of 2021 (Bobon, 2020). As the commercial aircraft activity has fallen by almost $40 \%$ in recent months, the production rate of commercial aircraft has been adapted accordingly. The new average monthly production rates set are: 40 of A320 aircraft, 2 of A330 aircraft and 6 of A350 aircraft. Airbus also received government support that allowed it to limit the measures needed to adapt to unprecedented crisis conditions. However, according to forecasts, air traffic is not expected to return to previous levels of COVID-19 before 2023 and potentially by 2025 .

Another impact of the recent crisis is the review by airlines of fleet development and used strategies, obviously with a massive impact on aircraft manufacturers. Not only the employees suffered but also the A380, B747 and B777 aircraft fleets. The COVID-19 pandemic has contributed to the early disappearance of the A380 aircraft from the fleets of some major companies, the market demand getting to smaller aircraft with low fuel consumption at the moment. The crisis has forced airlines worldwide to reconsider both strategies and fleet composition to reduce costs and remain operationally efficient. To reduce costs, Lufthansa had to remove 100 aircraft from its fleet and stop Germanwings operations. It has already eliminated 22 of its aircraft: 5 of Boeing 747-400, 6 Airbus of A380 and 11 Airbus of A320. Lufthansa Group said in a press release that: "The financial planning up to 2023 provides for the acceptance of a maximum of 80 new aircraft in the fleets of Lufthansa Group carriers' fleet. This will reduce the investment volume for new aircraft by half" (Prokopovič, 2020). During the same period, the last QF 747 flight of the last Qantas Boeing 747 jumbo has already taken place. Nearly five decades of mutual history of the "Queen of Heaven" and Australia's national carrier are now over. 


\section{Forecasts}

The return scenarios established by IATA for April 2020 and on indicate for 2025 a traffic lowered by only $10 \%$ compared to the 2019 forecasts. (Figure no. 7).

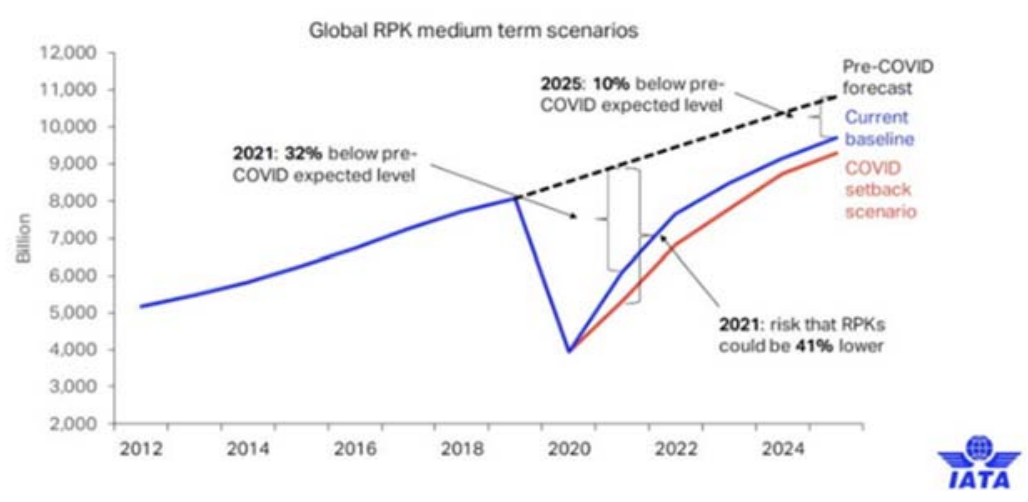

Figure no. 7. Global RPK medium term scenarios Source: IATA Economics, 2020

ACI (ACI - Europe, 2021) has managed to make some prediction on the return of passenger traffic in Europe for 2021, by quarters (Figure no. 8).

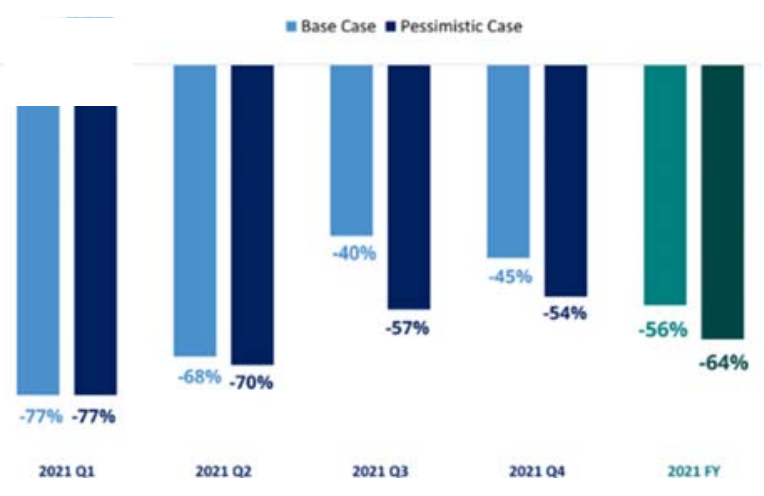

Figure no. 8. Passenger Traffic Forecasts by Quarter Source: ACI-Europe, 2021

The chief executive of Ryanair is mor optimistic and considers that it is feasible to reach $75-80 \%$ of pre-Covid levels in 2021, especially if the vaccine becomes available in 2021.

\section{Conclusions}

Although aviation was reduced by $-98 \%$ during the pandemic, it continued to fulfil its crucial social role as far as possible. Its part was to reunite families by repatriating tens of thousands of citizens from all over the world, saving lives by transporting the sick or injured ones, as well as massive amounts of medical supplies and consumer goods needed worldwide. Aviation has been of great support to governments, physicians and researchers' efforts, enabling all of them to carry out its essential missions along this arduous, complicate and still hard to fix standing.

Keeping travel restrictions prospects in Europe and the associated uncertainty keep altering the confidence in international travel and have a bad influence on air transport demand. The transformation 
of airlines might be based mainly on changing their internal business model, reorganizing its support functions and continuing to reduce external and internal costs to survive. The traffic reduction has already a domino effect and will generate redundancies at the aircraft manufacturers level in the years to come because of both orders cancellations and postponements.

Aviation needs support to continue living, rescuing and giving millions of passengers who have enjoyed all its economic and social benefits in recent years hope to travel safely and secured. Aviation undoubtedly remains a relevant service, as long as teleportation is a subject of science fiction movies for the time being.

\section{References}

ACI - Europe, 2020. COVID-19, Update \# 39, \# 76, \#83, [online] Available at: <https://www.acieurope.org/industry-topics/covid-19.html> [Accessed 30 March 2021].

ACI - Europe, 2020. Press Release, Brussels, [online] Available at: <https://www.acieurope.org/press-release.html $>$ [Accessed 28 March 2021].

ACI - Europe, 2021. COVID-19\& AIRPORTS Traffic Forecast \& Financial Impact, [online] Available at: <https://www.aci-europe.org/industry-topics/covid-19.html> [Accessed 30 March 2021].

Airbus, 2020. Airbus plans to further adapt to COVID-19 environment, [online] Available at: $<$ https://www.airbus.com/newsroom/press-releases/en/2020/06/airbus-plans-to-further-adapt-tocovid19-environment.html.> [Accessed 30 March 2021].

ATAG, 2020. Aviation benefits beyond borders, [online] Available at: $<$ https://aviationbenefits.org $>$ [Accessed 30 March 2021].

BBC News, 2020. German airline Lufthansa plans to cut 22,000 jobs, 11th of June 2020, [online] Available at: <https://www.bbc.com/news/business-53007048> [Accessed 15 April 2021].

Bobon, G., 2020. Airbus concediază 15 mii de angajați din cauza crizei cauzate de pandemie, [online] Available at: <https://boardingpass.ro/airbus-concediaza-15-mii-de-angajati-din-cauza-crizeicauzate-de-pandemie/> [Accessed 15 April 2021].

Digi 24, 2020. Concedieri masive la TAROM: 400 de angajați dispar din schema de personal, $25^{\text {th }}$ of June 2020, Available at: <https://www.digi24.ro/stiri/economie/transporturi/concedieri-masive-latarom-400-de-angajati-dispar-din-schema-de-personal-1328552> [Accessed 15 April 2021].

E. Măzăreanu, Coronavirus: impact on the aviation industry worldwide - Statistics \& Facts, [online] Available at: $<$ https://www.statista.com/topics/6178/coronavirus-impact-on-the-aviation-industryworldwide/> [Accessed 14 April 2021].

Flightradar24, Scraping along the bottom: April air traffic statistics, [online] Available at: $<$ https:/www.flightradar24.com/blog/scraping-along-the-bottom-april-air-traffic-statistics/> [Accessed 14 July 2021].

IATA Economics, 2020. COVID-19 Outlook for the airline industry 2020-2021, [online] Available at: $<$ https://www.iata.org/en/iata-repository/publications/economic-reports/airline-industryeconomic-performance-june-2020-presentation/> [Accessed 4 March 2021].

IATA, 2021. Full-year global passenger traffic, [online] Available at: $<$ https://www.hospitalitynet.org/news/4102868.html > [Accessed 12 April 2021].

Oxford Economics, 2020. Coronavirus update, [online] Available at: $<$ https://www.oxfordeconomics.com/coronavirus $>$ [Accessed 10 April 2021].

Prokopovič, K., 2020. Air France and HOP! to Cut Over 7,500 Jobs in Three Years, in Aviation Voice, 7th of July 2020, [online] Available at: $<$ https://aviationvoice.com/air-france-and-hop-to-cut-over7500-jobs-in-three-years-202007071540/> [Accessed 13 April 2021].

Prokopovič, K., 2020. Avolon Cancels Order for Additional 27 Boeing 737 MAX Aircraft, in Aviation Voice, [online] Available at: <https://aviationvoice.com/avolon-cancels-order-for-additional-27boeing-737-max-aircraft202007081230/?utm_source=newsletter\&utm_medium=email\&utm 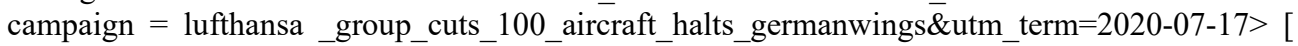 13 April 2021]. 
Prokopovič, K., 2020. Lufthansa Group Cuts 100 Aircraft; Halts Germanwings, [online] Available at: $<$ https://aviationvoice.com/lufthansa-group-cuts-100-aircraft-halts-germanwings-2-

202007081102/?utm_source=newsletter\&utm_medium=email\&utm_campaign=lufthansa_group_ cuts_100_aircraft_halts_germanwings\&utm_term=2020-07-15> [Accessed 15 April 2021].

TradeVille, 2020. Informatii despre sectorul aviatic, [online] Available at: $<$ https://www.tradeville.eu/cotatii-si-analize/rapoarte-diverse-pg2> [Accessed 15 April 2021]. 